\title{
砕波段波衝突による衝撃波力について* \\ IMPULSIVE FORCE ON WALLS DUE TO THE COLLISION OF A BORE
}

\author{
松冨英夫** \\ By Hideo MATSUTOMI
}

\begin{abstract}
An analytical procedure is developed for predicting the time-dependent impulsive force on vertical walls due to the collision of a bore. The impulsive force is estimated by using Cumberbatch's theory which treats the problem of a water wedge striking a wall. The comparison of the theoretical and experimental results shows that the present theory well estimates the total impulsive force and maximum impulsive pressure when the depth of water in the downstream region of the bore is sufficiently small compared with the height of the bore front.
\end{abstract}

Keywords: impulsive force, bore, dam-break flow, tsunami

\section{1. まえがき}

ドライ・ベッド上のサージング・フロント衝突による 構造物なよ゙への衝撃波力評価に関する理論的研究とし て, Cross の研究 ${ }^{3)}$ が代表としてある．彼の研究は，陸 上遡上津波を対象とした，ゲート急開流れのサージン グ・フロントにCumberbatch 理論4)適用したもので ある. その結果の有用性も実験值との比較により確認さ れている.

一方，下流側水深を有する砕波段波衝突による衝撃波 力の理論的推定を試みた研究例はほとんどない. 同じく, 津波を対象としたゲート急開流れの砕波段波に Cumberbatch 理論を適用した，Cross の研究が挙げられる程 度である. しかし，その研究にしても完全に理論的なわ けではない。衝撃波力評価の際に必要亡される段波の水 面形（正確には水面勾配と水深）や段波移動速度などに 実験值が用いられている．それらの理論的推定がまだ困 難な研究の進捗状況であったためである.

本研究は, 著者が対象段波の水面形や移動速度などの

* 本論文は文献 1) と2）の内容を有機的にまとめ, 考察を 加えたものである.

** 正会員 工修 秋田大学助手 鉱山学部土木工学科 ( 个010 秋田市手形学園町 1-1)
理論的推定を可能にしたので5)，その理論を Cross の考 えに適用することで, 砕波段波衝突による衝撃波力の完 全な理論的推定を試みようとするものである。

その理論結果の妥当性は実験値との比較により検討さ れる.しかし, 全衝撃波力の経時変化に関する既往の実 験データは 1 つしかい.このデータが精度よいものか ビうかは検討結果の信頼性に関係する．検討結果の信頼 性を高めるには，多くの実験データとの比較・検討が不 可欠と思われる. また, 今後のこの種の研究の発展のた めにも，利用できる実験デー夕の蓄積は重要である. そ のため，新たに実験を行い，理論結果の妥当性を検討す ることにする．実験デー夕の提供ということも本研究の 目的の 1 つである.

\section{2. 理 論}

本研究は, 図一1 に示すように, 初期下流側水深と流 速を有する場合のゲート急開流れの砕波段波が鉛直壁に 衝突するときで, 静水圧が支配的とならない, 段波衝突 後の比較的短い間での波力を対象亡する. すなわち，全 体からみれば小さい全静水圧と砕波段波のもつ運動量が 力積に変換されたときの全圧力（一般に，この全圧力を 衝撃波力之よぶ）との合力を対象にする. 本研究ではこ の合力を全波力または全衝撃波力とよんでいる. 


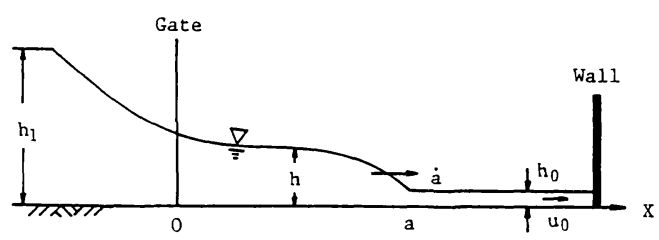

図一1 対象段波と想定壁面

Crossに従えば, Cumberbatch 理論を用いて, 対象 段波衝突による全 (衝撃) 波力 $F$ は近似的に次式で推 定される3).

$$
\begin{aligned}
& F=\frac{1}{2} \rho g h^{2}+C_{F} \rho u^{2} h \\
& C_{F}=1+(\tan \theta)^{1.2} \ldots \ldots
\end{aligned}
$$

ここで, $\rho:$ 水の密度, $g$ : 重力加速度, $h$ と $u:$ おの おの衝突壁がないときの壁の据えられる位置での入射段 波の全水深と断面平均水平方向水粒子速度, $\tan \theta(>$ $0)$ : 水面勾配, $C_{F}$ : force coefficient とよばれるもの で4), 式 (2) はCumberbatch 理論の近似として Cross により導かれたものである. 式（1）の右辺第 1 項が静 水圧項, 第 2 項が運動量が力積に変換されたときの全圧 力項である. 水面勾配にかかっている指数 1.2 はその近 似の程度により多少変化し得るものである.

本来ならば, Cumberbatch 理論は下流側水深を有す る段波には適用できない. 段波内部の流況はCumberbatch 理論で想定されている（ドライ・ベッド上の流れ の）流況と異なるからである.しかし，本研究例のよう に，段波下流側水深 $h_{0}$ が段波波高に比べて十分に小さ い場合は (図一3，8，9，10参照), 下流側水深有無によ る流れ先端部での流況の差はさほど大きくないものと考 えられる. 本研究で示される方法は, 段波下流側水深が 段波波高に比べてかなり小さい場合にのみ，適用可能な ものなのである.

全波力の経時的変化は, 式 (1) と（2）から判断さ れるように，衝突壁がないときの壁の据えられる位置で の入射段波の時々刻々の水深, 水面勾配亡流速が与えら れれば，推定可能となる. 本研究ではその水深と水面勾 配をおのおの著者の水深に関する次の理論式 ${ }^{5)}$;

$$
\begin{aligned}
& \xi \leqq \leqq \xi_{0} \text { で } \\
& h=2 \sqrt[3]{\beta} \cos \frac{\varphi}{3}+\frac{2}{3 g} S_{5}(\dot{a}-U)^{2} \frac{a-\xi}{a-x} \cdots \cdots . \\
& \beta=\sqrt{-\frac{m^{3}}{27}, \quad \cos \varphi=-\frac{q}{2 \beta},} \\
& m=-\left\{\frac{4}{3 g^{2}} S_{5}^{2}(\dot{a}-U)^{4}\left(\frac{a-\xi}{a-x}\right)^{2}\right. \\
& \quad-\frac{4}{g} S_{5}\left(\dot{a}-u_{0}\right)(\dot{a}-U) h_{0} \sqrt{\frac{a-\xi}{a-x}} \\
&\left.\quad+\frac{2}{g}\left(\dot{a}-u_{0}\right)^{2} h_{0}+h_{0}^{2}+\frac{2}{g} K U^{2}(a-x)\right\},
\end{aligned}
$$

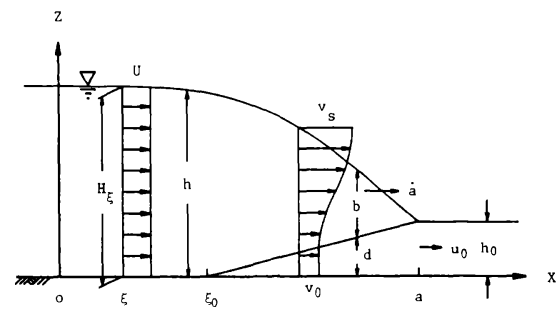

図一2 段波先端モデルと記号

$$
\begin{aligned}
q= & -\frac{2}{3 g} S_{5}(\dot{a}-U)^{2} \frac{a-\xi}{a-x}\left\{\frac{8}{9 g^{2}} S_{5}^{2}(\dot{a}-U)^{4}\right. \\
& \cdot\left(\frac{a-\xi}{a-x}\right)^{2}-\frac{4}{g} S_{5}\left(\dot{a}-u_{0}\right)(\dot{a}-U) h_{0} \\
& \cdot \sqrt{\frac{a-\xi}{a-x}}+\frac{2}{g}\left(\dot{a}-u_{0}\right)^{2} h_{0}+h_{0}^{2} \\
& \left.+\frac{2}{g} K U^{2}(a-x)\right\}+\frac{2}{g} \frac{S_{2}}{S_{1}^{2}}\left(\dot{a}-u_{0}\right)^{2} h_{0}^{2}, \\
S_{1}= & \frac{1}{12}(4+A), \quad S_{2}=\frac{1}{5}+\frac{A}{15}+\frac{A^{2}}{105}, \\
S_{5}= & 1-\frac{S_{2}}{S_{1}^{2}},
\end{aligned}
$$

$\xi_{0} \leqq x \leqq a$ で

$$
\begin{aligned}
& h\left(\frac{S_{2}}{S_{1}^{2}} \frac{h}{h-d}-1\right)\left(v_{0}-\dot{a}\right)^{2}+2 h_{0}\left(\dot{a}-u_{0}\right) \\
& \cdot\left(\frac{S_{2}}{S_{1}^{2}} \frac{h}{h-d}-1\right)\left(v_{0}-\dot{a}\right)+\frac{S_{2}}{S_{1}^{2}} \frac{\left(\dot{a}-u_{0}\right)^{2}}{h-d} h_{0}^{2} \\
& +\frac{g}{2} h^{2}-\left(\dot{a}-u_{0}\right)^{2} h_{0}-\frac{g}{2} h_{0}^{2} \\
& -K U^{2}\left(1-\frac{d}{h_{0}}\right)\left(a-\xi_{0}\right)=0
\end{aligned}
$$

とそれらを空間微分して得られる次式;

$\xi \leqq x \leqq \xi_{0}$ で

$$
\begin{aligned}
\tan \theta= & -\frac{\partial h}{\partial x} \\
= & -\frac{2}{3} \beta^{-2 / 3} \frac{\partial \beta}{\partial x} \cos \frac{\varphi}{3} \\
& +\frac{2}{3} \beta^{1 / 3} \frac{\partial \varphi}{\partial x} \sin \frac{\varphi}{3}-\frac{2}{3 g} S_{5}(\dot{a}-U)^{2} \frac{a-\xi}{(a-x)^{2}}
\end{aligned}
$$

$$
\begin{aligned}
\frac{\partial \beta}{\partial x}= & \left(-\frac{m}{12}\right)^{1 / 2}\left\{\frac{8}{3 g^{2}} S_{5}^{2}(\dot{a}-U)^{4} \frac{(a-\xi)^{2}}{(a-x)^{3}}\right. \\
& -\frac{2}{g} S_{5}\left(\dot{a}-u_{0}\right)(\dot{a}-U) h_{0} \frac{(a-\xi)^{1 / 2}}{(a-x)^{3 / 2}}-\frac{2}{g} \\
\frac{\partial \varphi}{\partial x}= & \frac{1}{2 \beta}\left(1-\frac{q^{2}}{4 \beta^{2}}\right)^{-1 / 2}\left[-\frac{2}{3 g} S_{5}(\dot{a}-U)^{2}\right. \\
& \cdot \frac{a-\xi}{(a-x)^{2}}\left\{\frac{24}{9 g^{2}} S_{5}^{2}(\dot{a}-U)^{4}\left(\frac{a-\xi}{a-x}\right)^{2}\right. \\
& -\frac{6}{g} S_{5}\left(\dot{a}-u_{0}\right)(\dot{a}-U) h_{0}\left(\frac{a-\xi}{a-x}\right)^{1 / 2} \\
& \left.\left.+\frac{2}{g}\left(\dot{a}-u_{0}\right)^{2} h_{0}+h_{0}^{2}\right\}-\frac{q}{\beta} \frac{\partial \beta}{\partial x}\right],
\end{aligned}
$$$$
\left.-\frac{2}{g} S_{5}\left(\dot{a}-u_{0}\right)(\dot{a}-U) h_{0} \frac{(a-\xi)^{1 / 2}}{(a-x)^{3 / 2}}-\frac{2}{g} K U^{2}\right\},
$$ 


\section{$\xi_{0} \leqq x \leqq a$ で}

$$
\begin{aligned}
\tan \theta= & \left\{\left(\dot{a}-v_{0}\right)^{2} h_{0} h-2\left(\dot{a}-v_{0}\right)\left(\dot{a}-u_{0}\right) h_{0}^{2}-\frac{g}{2} h_{0} h^{2}\right. \\
& +\left(\dot{a}-u_{0}\right)^{2} h^{2}+\frac{g}{2} h_{0}^{3}+K U^{2}\left(h+h_{0}-2 d\right) \\
& \cdot\left(a-\xi_{0}\right)-2 K U^{2}\left(d-S_{5} h\right)\left(\frac{h}{d}-\frac{h_{0}}{d} \frac{\dot{a}-u_{0}}{\dot{a}-v_{0}}\right) \\
& \left.\cdot\left(a-\xi_{0}\right)\right\} /\left\{\left(\dot{a}-v_{0}\right)^{2}\left(d-2 S_{5} h\right)\right. \\
& +2 S_{5}\left(\dot{a}-v_{0}\right)\left(\dot{a}-u_{0}\right) h_{0}+\frac{3}{2} g h^{2}-g h d \\
& -\left(\dot{a}-u_{0}\right)^{2} h_{0}-\frac{g}{2} h_{0}^{2}-K U^{2}\left(1-\frac{d}{h_{0}}\right)\left(a-\xi_{0}\right) \\
& \left.-2 g\left(d-S_{5} h\right)\left(h-\frac{\dot{a}-u_{0}}{\dot{a}-v_{0}} h_{0}\right)\right\}\left(a-\xi_{0}\right)
\end{aligned}
$$

で評価することにする．ここで, $x:$ ゲート位置を原点 とし, 下流方向を正とする水平距離座標， $a$ : 段波先端 位置, $\xi$ : 段波後端位置, $\xi_{0}$ : コア領域終端位置, $\dot{a}$ : 段波先端移動速度, $U$ : 段波後端での断面平均水平方向 水粒子速度, $v_{0}$ : 底面での水粒子速度, $u_{0}$ : 初期のゲ一 卜下流側での断面平均水粒子速度, $d:$ :コ厚, $K$ : 抵 抗係数, $A$ : 段波内の水平方向水粒子速度の鉛直分布に 関する定数である. また, 流速 $u$ には，近似的に $x=\xi$ での流速 $U(\fallingdotseq \dot{a})$ を採用することにする．これは，波 力評価に用いている Cumberbatch 理論が, ドライ・ベッ ド上の波形不変な（流れ方向に流速一樣で, 流速=流れ 先端移動速度となる) 流れの衝突に対するものであるこ とによる。

著者の水面形推定法における段波のモデル化では，水 平方向水粒子速度の鉛直分布を考慮している ${ }^{5)} . u$ とし て，段波各点（段波が移動していることより，このよう にも表現される）での断面平均流速を採用するのが，理 論的に整合性がある。事実, 全衝撃波力に関しては，そ の方が段波の立ち上がり部分で実験値によりょく一致す る. しかし，著者のモデルでは，段波先端に近づくにつ れて, $u$ が単調减少的に $u_{0}(\ll \dot{a})$ に近づき, 波圧も単 調减少的に小さくなる（ピークをもたない）という不合 理を生じる.理論的に整合性のある方法を採用するには, Madsen and Svendsen のような とならない, より厳密な段波モデルを採用する必要があ ろう。ここで， $v_{s}$ は水表面での水平方向水粒子速度で, 彼らの場合, $u_{0}=0$ である.

とはいうものの, 波力評価に Cumberbatch 理論を用 いていることを考えると，本研究のように水面勾配を正 確に求め, 段波内全体で流速 (段波移動速度に近いもの) が同じというモデルの方がよいかもしれない，対象段波 の場合 $\left(\theta<45^{\circ}\right)$, 式 (1) の静水圧項は小さいと考え
ると（次章 (1) 節の計算例で示される), 水面勾配の 推定精度次第で, 全波力は倍程度に変化し得るものであ る.これについては，文献 3$)$ の図一7 を参照されたい. 本研究では， $A$ の値として 2.0 を採用している. $a$, $\xi や \xi_{0}$ などの評価方法については, 文献 5) を参照され たい。 また，対象段波の水面形推定における段波のモデ ル化と式中の諸記号については, 図一2 を参照されたい.

ところで，式（6）は段波先端 $(x=a)$ で $0 / 0$ の不 定形となる。このままでは段波衝突時の全衝撃波力や衝 撃波圧を評価することができない，本理論ではこのとき に最大衝撃波圧を生じ (たとえば，図一3(c) 参照)，そ の評価は非常に重要である，そこで，不定形の極限值を 得る手法でその解を求めることにする. その結果として, 次式が得られる.

$$
\begin{aligned}
(\tan \theta)_{x=a}=\frac{1}{J_{3}}\left(J_{1}+\sqrt{J_{1}^{2}-J_{2} J_{3}}\right) \cdots \cdots \cdots \cdots \cdots \cdots(7) & \\
J_{1}= & \frac{1}{a-\xi_{0}}\left\{\left(\dot{a}-u_{0}\right)^{2} h_{0}-g h_{0}^{2}\right\}-K U^{2}\left(2 \frac{S_{2}}{S_{1}^{2}}-1\right) \\
& +2 K U^{2} \frac{g h_{0}}{\left(\dot{a}-u_{0}\right)^{2}} \frac{S_{2}}{S_{1}^{2}}, \\
J_{2}= & 2 K^{2} \frac{U^{4}}{\left(\dot{a}-u_{0}\right)^{2}} \frac{S_{2}}{S_{1}^{2}}-2 K U^{2} \frac{h_{0}}{a-\xi_{0}}, \\
J_{3}= & -2 S_{5}\left(\left(\dot{a}-u_{0}\right)^{2}-g h_{0}\right\}-2 g h_{0}\left\{1-\frac{g h_{0}}{\left(\dot{a}-u_{0}\right)^{2}}\right\} \frac{S_{2}}{S_{1}^{2}} .
\end{aligned}
$$

ここで, 添字 $x=a$ は段波先端での値であることを表わ す.

\section{3. 解の適用性}

本理論の実際問題への適用性について, 実験結果との 比較を通して検討することにする.

\section{（1） 既往実験值との比較}

波力の実験は難しいこともあってか, 特に本研究対象 の段波衝突による波力の実験例は少ない。入射段波条件 や全波力の経時変化などもはっきりしている実験值とし ては，Cross のものが利用できる程度である．それも， 一実験值の利用ができるだけで，初期ゲート上流側水深 $h_{1} \doteqdot 0.366 \mathrm{~m}, h_{0} \doteqdot 0.006 \mathrm{~m}, u_{0} \doteqdot 0 \mathrm{~m} / \mathrm{s}$, 底面勾配 $i \fallingdotseq$ 0.002 の条件のもとで得られたものである.ただし，段 波衝突直後に発生する最大衝撃波圧に関しては, 福井ら のものが利用できる7). そこでまず，Cross の実験值と 福井らの実験值や実験式との比較により, 本研究で示さ れた理論的手法の妥当性を検討することにする.

図一3(a) は入射段波水位の経時変化の比較を示した ものである. ゲート地点からの距離 $x \doteqdot 4.7 \mathrm{~m}$ でのもの である. 水位の立ち上がり始めをともに時間の原点 $(t$ =0）としてある．理論值は段波を進行させ，想定壁面 位置での水位変化を求めたものである. 抵抗係数として 


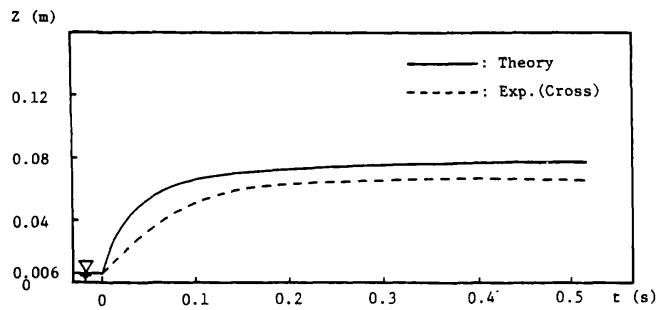

（a）入射段波水位の経時変化

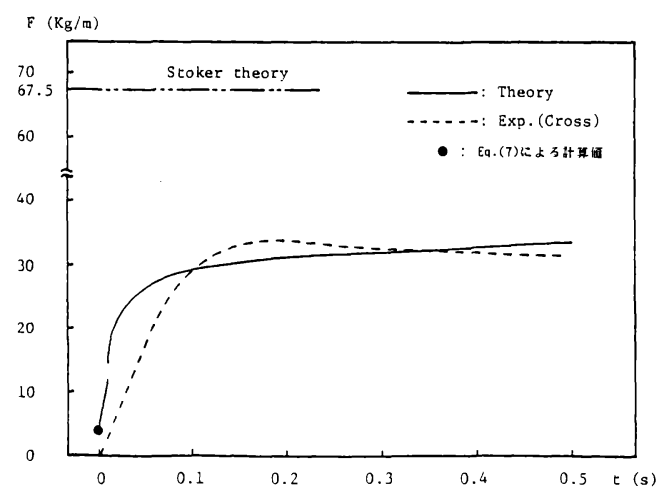

（b ）全衝擊波力の経時変化

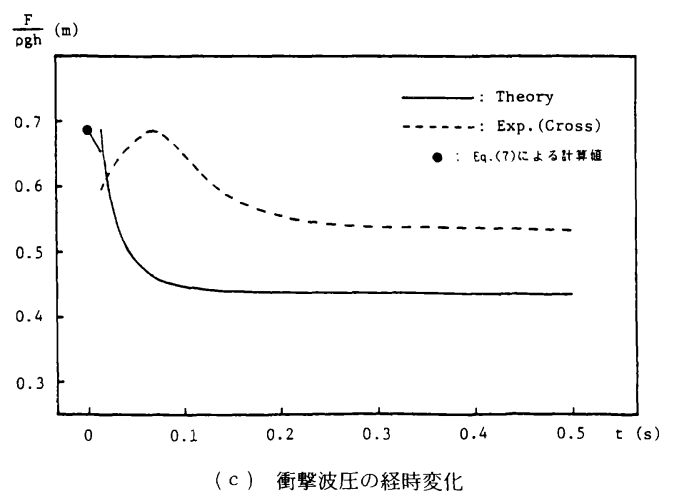

図一3 既往実験值と理論值の比較

は, Cross の与えた Chézy の流速係数 $C_{h}(=98)$ から 換算 $\left(K=g / C_{h}^{2} \fallingdotseq 0.001\right)$ されたものを採用している. 想定壁面位置を通過した後の段波の水面形と先端移動速 度 $\dot{a}$ は変わらないと仮定して, $t=0$ での空間波形を移 動させたときの水位変化もほぼ同じ結果となった。この 図によると, 理論値の方が全般的に実験值より大きい. 特に, $t=0.2 \mathrm{~s}$ までの水位の立ち上がり過程には大き な違いが認められる.この理由として，i）実験での $h_{0}$ の評価の正確性， ii）気泡を含んだ流れに対する波 高計の応答性や，iii）実験值は排水のことを考えて緩い 斜面上で得られたものであるが, 理論值は水平床として 評価されている，などが考えられる．特に，i）の段波
下流側水深は段波水深に大きな影響を及ぼすものであ る.これらの点については, 次節の本研究実験值との比 較において簡単に考察する.

図一3(b) は全波力の経時変化の比較を示したもので ある. ゲート地点からの距離 $x \fallingdotseq 5.1 \mathrm{~m}$ でのものである. 図には，段波衝突後鉛直方向に投げ出された流体塊が落 下してきたときに生じる，波力の増大部分までは示され ていない.その部分は研究対象外の波力だからである(次 節参照).この図によると，理論値と実験値は比較的よ く一致している. ちなみに，全波力のほぼ一定となって いる, $t=0.4 \mathrm{~s}$ 前後での理論における全静水圧の全波 力に占める割合は $10 \%$ 程度である.

本理論では，コア領域終端点（図-2の $x=\xi_{0}$ ）での 水面勾配が食い違っているため, 波力もその点で食い違 いをみせる、しかし，その大きさは最大全波力からみれ ば，無視できる程度であることが図一3(b) から判断さ れる. 図中には, Stoker 理論8)で評価される全静水圧も 合わせて示されている. ただし, 壁面衝突開始時の段波 と同一水理条件を有する理想的定常段波が, 壁面に衝突 して, 完全反射するときのものである. Stoker 理論で 評価される全静水圧は，段波衝突直後の短い間に形成さ れる全衝撃波力よりもかなり大きいようである. 衝撃的 な全波力の俨価には，本研究の方法がより合理的である と判断される.さらに, 図中には段波先端衝突時の水面 勾配として, 式（７）を用いて評価した全衝撃波力が黒 丸で示されている.この值は, $t=0$ のときの段波先端 $(x$ $=a ）$ 近傍での水深と水面勾配を用いて評価された波力 から, 外挿して求めたものとほぼ同じであった。

図一3(c) は衝撃波圧 $p$ の経時変化の比較を示したも のである. ゲート地点からの距離 $x \fallingdotseq 5.1 \mathrm{~m}$ でのもので あるが，段波水深に関する実験值は $4.7 \mathrm{~m}$ でのものを 用いている。ここで, 衝撃波圧は, 全波力 $F$ と段波水 深 $h$ を用いて, $p / \rho g=F / \rho g h$ で定義されている. 実 際の段波衝突後の衝撃波力の作用範囲は, 流体塊が鉛直 方向に投げ出されるため，入射段波水深幅よりも広い4). たとえば，次節で述べる $h_{1}=0.45 \mathrm{~m}$ の実験では，入射 段波水深 $h \fallingdotseq 0.13 \mathrm{~m}$ のときで, 作用範囲（投げ出され

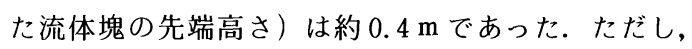
投げ出された流体塊部分での衝撃波力は小さいこと4), この波圧の定義での理論值と実験值の比較に問題はない ことを断っておく，この図によると，発生時刻に差がみ られるが, 理論と実験の最大衝撃波圧 $p_{m}$ （理論值は図 中の黒丸）はほぼ同じ值を示している。しかし，ほぼ一 定となる $t=0.1 \mathrm{~s}$ 以後での理論波圧は過小評価の傾向 にある.これは主に, 図一3(a) からも判断されるように, その領域での両者間の段波水位差に起因しているものと 推定される. 
$\mathrm{p}_{\mathrm{m}} \cdot \zeta(\mathrm{g} / \mathrm{cm})$

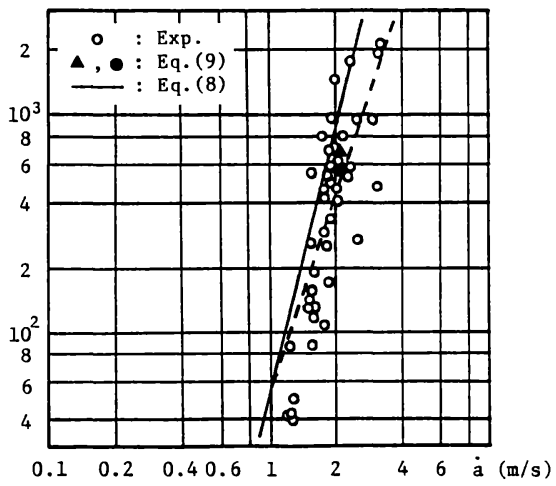

図一4 最大衝撃波圧に関する既往結果との比較

図一4 は図一3(c) に示された理論による最大衝撃波 圧 (黒丸) と最大衝撃波圧に関する福井ら ${ }^{7)}$ の実験式お よび実験值との比較を示したものである. 図中, 白丸が 実験值で, 黒丸 (黒三角) が理論值, すなわち式 (9・a) (式 $(9 \cdot b))$ で評価されたものである.この場合の理 論值は, 段波下流側水深が非常に小さいので（約 0.006 $\mathrm{m}$ ), 断面平均的な衝撃波圧 (本研究の衝撃波圧が $F / h$ で定義されていることによる）と考える必要はない．ま た，図中の実線が福井らの実験曲線で，鉛直壁に対する 彼らの実験式は次式である.

$$
p_{m} \zeta=0.51 \frac{\rho}{g} \dot{a}^{4}
$$

ここで, とは入射段波波高で, 本研究では $H_{\xi}-h_{0}$ に相 当する. $H_{\xi}$ は $x=\xi$ での全水深である. 図一 4 によると, 式（8）は実験值に対して少し大きめの值を与えるよう である. 実験係数である波圧係数 $(0.51)$ がもう少し小 さく評価されてもよいように思われる. 図中の破線は福 井らの論文 ${ }^{7)}$ の図一14 中に示されている実験曲線であ る.こちらの方が, 式（８）の実線に比べて, 実験值と の一致度がよい. 破線は段波伝播速度 $\dot{a}$ のほぼ 3 乗に 比例している.

式 (8) に相当する本研究の理論式は次式である.

$$
\begin{aligned}
p_{m} \zeta & \doteqdot F_{x=a}\left(\frac{H_{\xi}}{h_{0}}-1\right) \\
& =\rho\left\{1+(\tan \theta)_{x=a}^{1.2}\right\}\left(H_{\xi}-h_{0}\right) U^{2} \\
& \doteqdot \rho\left\{1+(\tan \theta)_{x=a}^{1.2}\right\}\left(H_{\xi}-h_{0}\right) \dot{a}^{2}
\end{aligned}
$$

ここで, 式 $(9 \cdot a)$ から式 $(9 \cdot b)$ への近似は, 段波下 流側水深が段波波高に比べて非常に小さいと想定しての ことである. 福井らの実験での最大衝撃波圧は段波下流 側の静水面位置で生じているので, 式（1）の静水圧項 は無視されている.ちなみに，本理論計算例でのその全 静水圧の全衝撃波力に対する割合は $1 \%$ 以下である. 図一4によると, 理論值は式（８）の実験式による推定
值に比べてかなり小さめ（約 $1 / 2 ）$ である.しかし，実 験值と比べると, ほぼ妥当なところに位置しており, 本 理論の実際問題への有用性が伺われる.

\section{（2）本研究実験值との比較}

利用できる既往の実験值は非常に少ない. 同一地点で の入射段波水位と全衝撃波力の経時変化に関する実験 デー夕は皆無である．また，それら実験值の精度も不明 である. 実験データの提供（蓄積）ということも含め, 本理論の妥当性に関する検討結果の信頼性を高めるため にも，実験を行う必要がある.

実験に使用した水路は高さ $0.5 \mathrm{~m}$, 幅 $0.3 \mathrm{~m}$, 長さ $11.0 \mathrm{~m}$ の水平に設置された鋼製矩形水路で, 水路下流 側の $10 \mathrm{~m}$ 部分が両面ガラス張りのものである. ガラス の片面には, 経時的流れ先端位置と空間波形読み取りの ため, $5 \mathrm{~cm}$ 間隔のメッシュが刻まれている. ゲートと して, 手動の引き揚げ式のもの (塩化ビニール樹脂製で, 厚さ $12 \mathrm{~mm}$ ) が用いられた. 水路下流端から $6 \mathrm{~m}$ のと ころに位置している. ゲート下流側水深調節のため, 水 路下流端に取り外し可能な堰も取り付けられた。 また, 波力測定には, 受圧板付きのしっかり之固定できる, L 型鋼棒が用いられた．受圧板は塩化ビニール樹脂製で, その諸元は $10 \times 295 \times 500 \mathrm{~mm}$ である. L型鋼棒の諸元 は断面 $40 \times 70 \mathrm{~mm}$, 固定時水平部長さ $550 \mathrm{~mm}$, 鉛直部 長さ $970 \mathrm{~mm}$ である.この波力計の固有振動数は, 受圧 板を取り付けた状態で, 約 $27 \mathrm{~Hz}$ である. 波力の評価に は, 防水ひずみゲージで鋼棒鉛直部のひずみを測定し, それを力に換算する方法が取られた．つまり，全波力の 測定が行われた。実験装置の概要を図一5に示す.

上述の波力测定法では, 波力計のキャリブレーション が問題となる. 合波力の作用点が時間的に移動するから である．本研究ではそれを，ばね科（科量 $50 \mathrm{~kg}$ ）を用 い, 全衝撃波力ピーク值付近（ほぼ一定值となる $t=$ $0.4 \mathrm{~s}$ 付近. 図一 $8(\mathrm{~b}), 9(\mathrm{~b})$ と $10(\mathrm{~b})$ を参照) の合波 力 (静水圧を除く) の作用点に対してのみ行った.つま

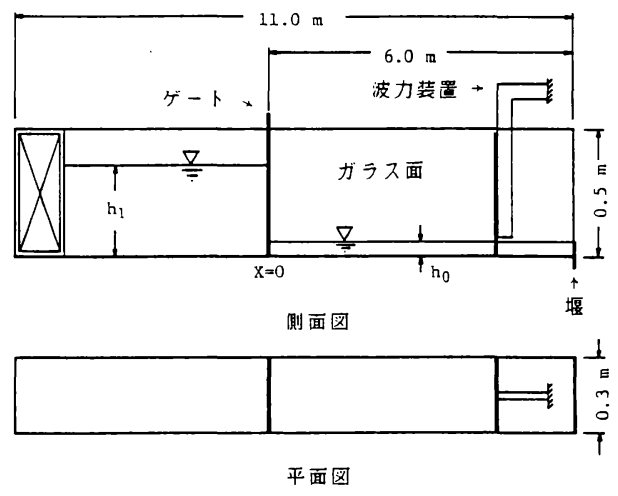

図一5 実験装置 
り，前節の衝撃波圧の定義から想像つくように，衝撃波 圧は底面から入射段波水位まで等分布的に働くと考え， 衝突壁がないときの, 全衝撃波力ピーク時付近での入射 段波水深の $1 / 2$ 点に対して行った. この結果のみを用い て波力を評価すると, ピーク前の波力が過大評価される ことになる. しかし，作用点をその移動範囲内 $(z=10$ 〜 66 mm) で変えてキャリブレーションを行ったところ, 本波力計では高々数\%であることを確認した。図一6に キャリブレーション結果例 $\left(h_{0}=0.02 \mathrm{~m}, h_{1}=0.4 \mathrm{~m}\right)$ を示す. 合波力の作用点は底面から $64 \mathrm{~mm}$ のここで ある，縦軸は載荷力で, 横軸はペン・レコーダ一記録紙 上の変位量である. 図中の前面・後面はひずみゲージの 貼り付けられたL型鋼棒（受圧板の取り付けられた鉛直 部）の側面を示す。上流側が前面で, 下流側が後面であ る. 前面と後面の結果はほぼ同じで, 直線性も非常によ い. 他の実験ケースでのキャリブレーション結果も同じ であった。

実験ケースは， $u_{0}$ と $h_{0}$ をおのおの零と $0.02 \mathrm{~m}$ に固 定し， $h_{1}$ を $0.35 \mathrm{~m}, 0.40 \mathrm{~m} ， 0.45 \mathrm{~m}$ とした 3 ケースで ある.ただし, 测定は各ケースとも, ゲート下流 $x=$ $3.87 \mathrm{~m}$ と $5.05 \mathrm{~m}$ の 2 か所で行われた.

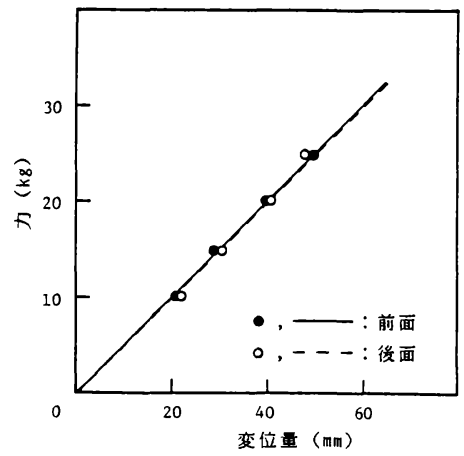

図一6 波力計のキャリブレーション $\left(h_{0}=0.02 \mathrm{~m}, h_{1}=0.4 \mathrm{~m}\right)$

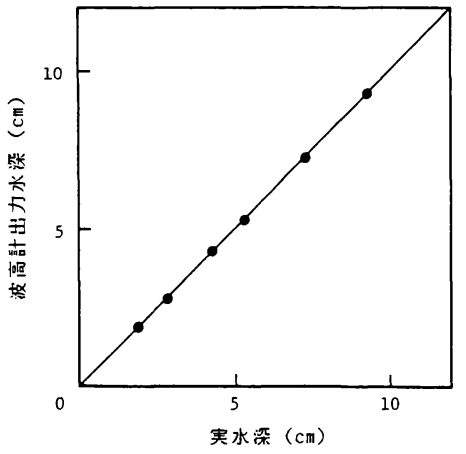

図一7 波高計のキャリブレーション
測定項目は全波力, 段波衝突前後の壁面近傍での水面 形，衝突壁前面 $0.4 \mathrm{~m}$ と $1 \mathrm{~m}$ での入・反射段波の時間 波形，衝突壁を取り除いたときの壁の据えられる位置で の入射段波の空間と時間波形である. 段波衝突前後の壁 面近傍での水面形の測定は, 段波衝突後にCumberbatch 理論で想定されているような水面形となるかどう かの確認, 鉛直方向に投げ出された流体塊の挙動の確認 なよ゙のために行われた。衝突壁前面での入・反射段波の 時間波形の測定は, Stoker 理論 ${ }^{8)}$ で予測される反射段波 水深の妥当性の確認などのために行われた.これらの測 定には，上述の波力測定装置のほかに，モーター・ドラ イブ・カメラ（約 5 コマ/秒）と容量式波高計が用いら れた. 波高計の使用に際し, 線形応答に必要な水深確保

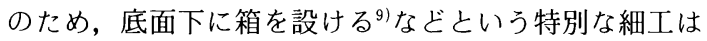
なされていない，図一7に波高計のキャリブレーション 結果を示す. 本実験ケースのように, 常に $h \geqq 0.02 \mathrm{~m}$ となる場合では, 直線性が非常によいことが判断される. 全波力と段波水位の経時変化の記録には, ペン・レコー ダーを用いた。

図一8(a), (b) と (c) に, $h_{1}=0.35 \mathrm{~m}, h_{0}=0.02 \mathrm{~m}$, $x=5.05 \mathrm{~m}$ での入射段波水位，全衝撃波力と衝撃波圧の 経時変化に関する実験値 (白丸) と理論値 (実線) の比 較を示す.ここで, 理論における抵抗係数 $K$ は, 従来 の滑面開水路抵抗則での水深に, Stoker 理論5),8) より計 算される理想段波水深を用いて推定されている. その值 はおよそ 0.002 である. 以下の理論計算でのそれも，す ベて同じ方法で推定されている. 滑面水路に対して，こ の方法が有効であることは確認済みである5)。また，衝 撃波圧に関する実験値は，入射段波水位と全衝撃波力の 均された時間波形から評価されている. 図一8(a) と (b) 中の破線がその均され，採用された時間波形で，以下の 図でも同じである.これは，同一段波で，しかも同一地 点でのそれらの実験值が得られないことによる便法であ る. 図-8(b) 中の二点鎖線亡黒丸，(c) 中の黒丸はお のおの図一3(b) と (c) 中のそれらと同じものを表わす. ちなみに, 本実験での反射段波水深（段波反射時の全静 水圧といってもよい) は, Stoker 理論で予測されるそ れより若干小さめの傾向であった。

図一 9 と 10 の $(\mathrm{a}),(\mathrm{b}),(\mathrm{c})$ はおのおの $\left(h_{1}=0.40 \mathrm{~m}\right.$, $\left.h_{0}=0.02 \mathrm{~m}, x=5.05 \mathrm{~m}\right)$ と $\left(h_{1}=0.45 \mathrm{~m}, h_{0}=0.02 \mathrm{~m}\right.$, $x=5.05 \mathrm{~m}$ ) での入射段波水位, 全衝撃波力之衝撃波圧 の経時変化に関する実験值と理論値の比較を示したもの である．残りの他のケースについては，文献 2) を参照 されたい.

図一 8,9 と 10 によると, 入射段波水位の経時変化に 関する理論值と本実験値の一致度は, Cross の実験値の ときと比較して（図一-3(a) 参照)，よくなっている. 特 


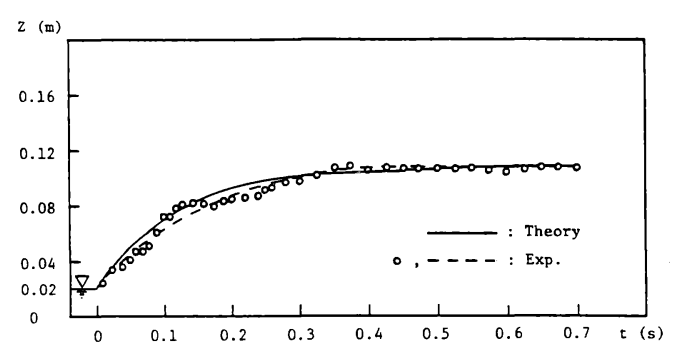

(a) 入射段波水位の経時変化

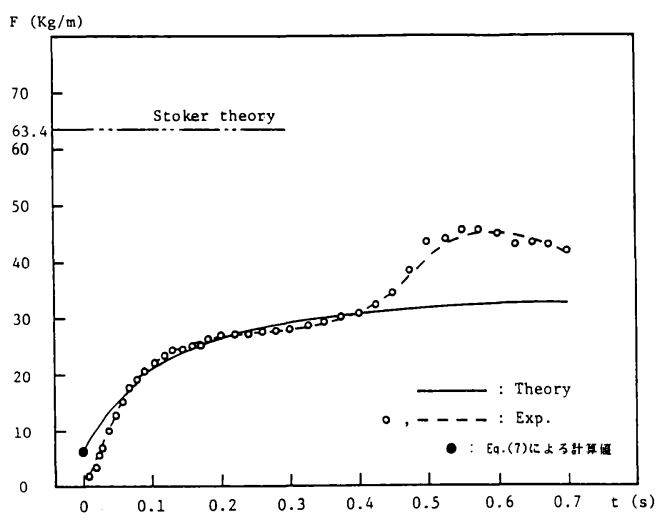

（b）全衝撃波力の経時変化

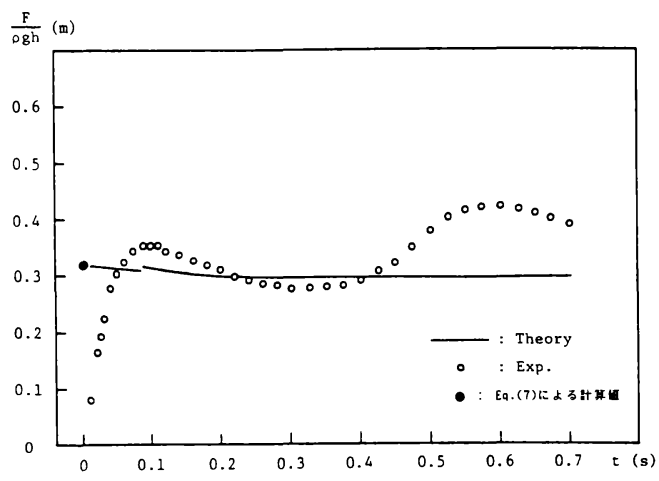

(c) 衝撃波圧の経時変化

図一8 実験値と理論值の比較 $\left(h_{1}=0.35 \mathrm{~m}, x=5.05 \mathrm{~m}\right)$

に, $h_{1}=0.35 \mathrm{~m}$ と $0.40 \mathrm{~m}$ の場合は, $t=0.2 \mathrm{~s}$ までの水 位の立ち上がり過程もよく一致している. 理論值と Cross の実験值との不一致は, 気泡などのあまり含まれ ない，ほぼ一定段波水深となる領域でも大きい． $h_{0}=$ $0.01 \mathrm{~m}$ ，その他は既述の条件之同一条件での付加実験 を行ったところ,これと同じ傾向の結果が得られた. Cross の実験值は, ゲート下流側水深が約 $0.006 \mathrm{~m}$ とい う非常に小さな条件で得られたものである. 波高計の線 形応答に必要な水深確保などという，特別な細工はなさ れていない (本実験でも同じ)。理論値とCross の実験 值との不一致は，主に波高計出力の線形性が十分に保た

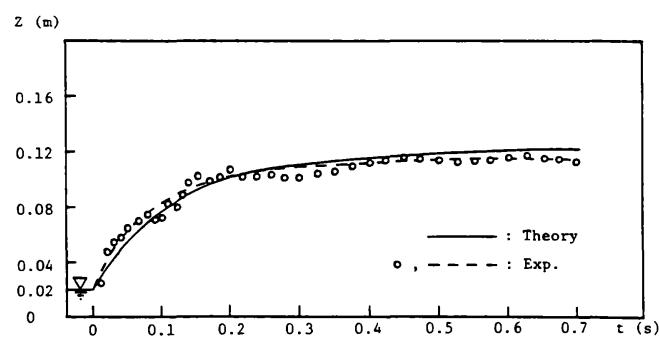

（a）入射段波水位の経時変化

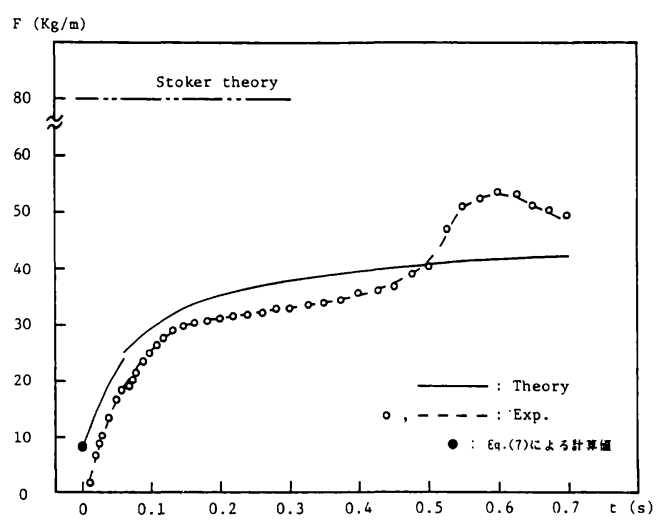

（b）全衝擊波力の経時変化

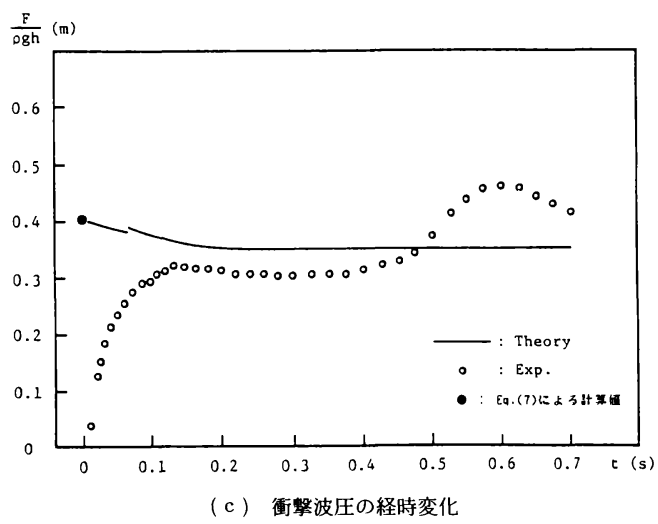

図一9 実験値と理論值の比較 $\left(h_{1}=0.40 \mathrm{~m}, x=5.05 \mathrm{~m}\right)$

れていなかったためでないかと思われる（本実験での波 高計のキャリブレーション結果については図一7を参 照).

全衝撃波力の経時変化に関する本実験値は, Cross の 実験值と同じ傾向を示している.ただし，どれも単調増 加しており，Cross の実験值でのような緩いピークはみ られない（図一3(b) 参照). $t=0.5 \mathrm{~s}$ 付近での立ち上 がりは, 段波衝突後鉛直方向に投げ出された流体塊が落 下してきたときに生じるものである．同じような立ち上 がりはCross の実験值でもみられる ${ }^{3)}$. ただし，その相 対的大きさは本実験值に比べて少し小さい. 本研究では, 


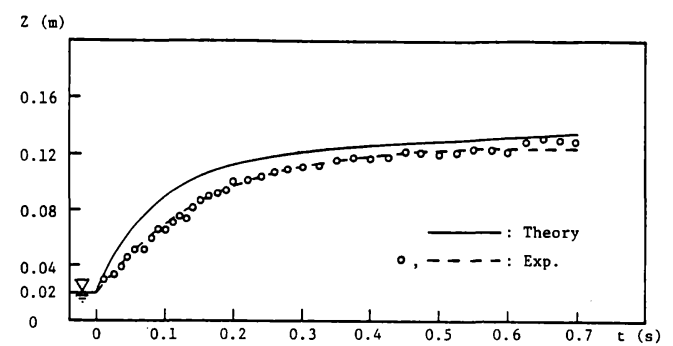

（a）入射段波水位の経時変化

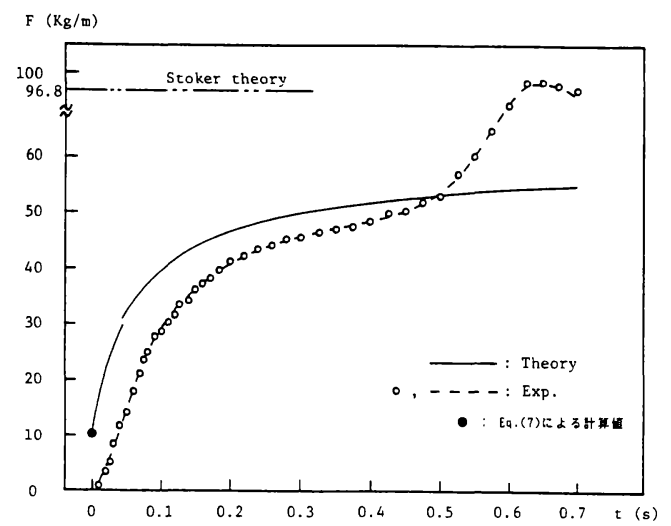

（b）全衝撃波力の経時変化

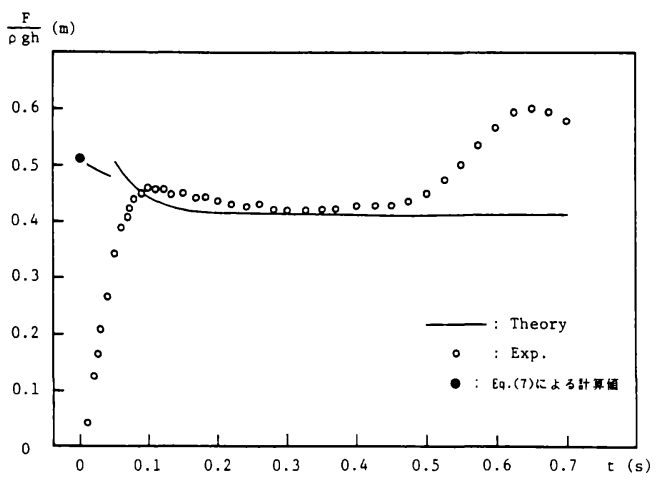

(c) 衝撃波圧の経時変化

図-10 実験值と理論値の比較 $\left(h_{1}=0.45 \mathrm{~m}, x=5.05 \mathrm{~m}\right)$

この立ち上がり前までの波力を衝撃波力としている．実 験値と理論值の一致度も比較的よい. 以上より, 全衝撃 波力に関するCross の実験值はほぼ妥当なものと判断 されよう.

衝撃波圧の経時変化に関する本実験値は, Cross の実 験值と全体的に同じ傾向を示している. しかし, 最大衝 撃波圧への立ち上がりが少し緩めの傾向にある. 最大值 の理論との一致度も, Cross の実験値のときと比べ, あ まりよくない。この理由の 1 つに, 本実験で動ひずみ測 定器の感度を落とし過ぎ, 全衝撃波力の立ち上がりが緩 慢になっていることが考えられる．その他として，実験
データの整理方法の問題（均されたデー夕を用いて評価 していること）などが考えられよう。

以上, 本研究理論の妥当性の検討を行った: 砕波段波 衝突による最大衝撃波圧や全衝撃波力の評価は工学上非 常に重要である. 本章 $(1)$ ・ ( 2 ) 節での検討結果より, 本研究理論の実際問題への有用性が確認されたと判断し てよい.

\section{4.むすび}

ゲート急開流れの砕波段波衝突による衝撃波力の一理 論的推定法を示した. 波力実験を行い, その推定法の妥 当性の検討と利用できる実験データの提供を試みた，既 往実験デ一タとの比較・検討もなされた. 本研究で得ら れた主要な結論は次のとおりである。

（1）本研究対象段波衝突による全衝撃波力は本研究 の方法で比較的精度よく推定できる。

（2）断面平均的衝撃波圧も，最大值とその後の平坦 部での値に関しては, 本研究の方法で比較的精度よく推 定できる。

（3）本理論では, コア領域終端点 $\left(x=\xi_{0}\right)$ での水 面勾配が不連続なため, 全衝撃波力や衝撃波圧もその点 で食い違いをみせる，しかし，その大きさは全体からみ れば小さく，本研究の方法の有用性を損なうものではな い.

（4）全衝撃波力に関するCross の実験値はほぼ妥 当なものと判断される.

（5）同一地点での入射段波水位と全衝撃波力の経時 変化に関する実験データの提供がなされた。それらの均 された時間波形を用いて，衝撃波圧の経時変化に関する データの提供もなされた。ただし，最大衝撃波圧に関し ては，あまり精度よい結果が得られていない。

謝辞：本研究を遂行するにあたり, 東北大学工学 部 首藤伸夫教授と秋田大学鉱山学部 浅田 宏教授より 有益なるご助言, ご意見を賜った。ここに記して両先生 に深甚なる感謝の意を表する. また, 理論解析と実験に 助力頂いた本学卒業生 楢岡善治君亡栗田純次君にも感 謝の意を表する. なお, 本研究は昭和 62 年度文部省科 学研究費自然災害特別研究（1）（研究代表者：首藤伸 夫教授）と奨励研究（A）により行われたことを付記す る.

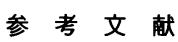

1）松富英夫・浅田 宏・楢岡善治：砕波段波衝突による波 力の一評価方法, 第 34 回海講論文集, pp. 522 525, 1987.

2）松冨英夫：砕波段波衝突による波力に関する実験, 東北 大学工学部津波防災実験所研究報告, 第 5 号, pp. 15 31, 1988. 
3) Cross, R.H. : Tsunami surge forces, Proc. ASCE, Vol. 93, WW4, pp. 201 231, 1967.

4) Cumberbatch, E. : The impact of a water wedge on a wall, J.F.M., Vol.7, pp. 353 374, 1960.

5）松富英夫：下流側水深を有するダム破壊流れ先端部の水 面形, 土木学会論文集, No. 375/II-6, pp. 161 170, 1986.

6) Madsen, P. A. and Svendsen, I. A. : Turbulent bores and hydraulic jumps, J.F.M., Vol.129, pp.1 25, 1983.
7) Fukui, Y., Nakamura, M., Shiraishi, H. and Sasaki, Y. : Hydraulic study on tsunami, Coastal Eng. in Japan, Vol. 6, pp. 67 82, 1963.

8) Stoker, J. J. : Water Waves, Interscience Publishers, Inc., New York, 1957.

9）たとえば，松冨英夫：津波のサージング・フロント，土 木学会論文集, No. 375／II-6, pp. 231２39，1986.

(1988.2.15 - 受付) 